\title{
Energy, unemployment and trade
}

\author{
Shuddhasattwa Rafiq ${ }^{a^{*}}$ Ruhul Salim ${ }^{b}$ Pasquale M Sgro ${ }^{a}$ \\ ${ }^{a}$ Deakin Graduate School of Business \\ Faculty of Business \& Law \\ Deakin University \\ 221 Burwood Highway, Melbourne, \\ Victoria 3125 Australia \\ ${ }^{\mathrm{b}}$ School of Economics and Finance \\ Curtin Business School, \\ Curtin University, \\ Perth, WA 6845, Australia.
}

Curtin University

*Corresponding author

Acknowledgement: Our heartiest thanks to Professor Yongcheol Shin and Professor Tolga Omay for their kind supports in implementing Kapetanios et al. (2014) and Emirmahmutoglu and Omay (2014) non-linear panel estimations. 


\title{
Energy, unemployment and trade
}

\begin{abstract}
This article investigates the dynamic relationships among sectoral economic activities, macro expenditure patterns, renewable and non-renewable energy consumption and unemployment in 41 countries from 1980 to 2011. The state of the art econometric techniques, both linear and non-linear panel estimation techniques are used. The results show that industrialization, services sector, government expenditure and trade openness play a positive role in reducing unemployment, while agriculture and renewable energy consumption increase unemployment. This might be, in part, due to recent technological advancements and large capital intensive investments in agriculture and renewable energy sectors.
\end{abstract}

Keywords: renewable energy consumption; unemployment; sectoral restructure, panel data; nonlinearity.

JEL Classification: Q20; E24; C33 


\section{Energy, unemployment and trade}

\section{Introduction}

World economies experience large scale reallocations of employment and capital as they grow over time and these reallocations lead to a gradual transformation of these economies (Comin, et al 2015). During the 1980s and 1990s as Ljungqvist and Sargent (1998) argue that the rapid restructuring from manufacturing to service industry, the adoption of new information and communication technologies, and the increasing global competition are major sources of European unemployment. In another study on investigating the effects of sectoral shifts on unemployment, Lilien (1982) presented evidence that most of the unemployment fluctuations of the seventies in the US were induced by unexpected structural shifts. Other studies, such as Layard et al., 1991 also demonstrate that structural changes contributed to aggregate unemployment in OECD (Organization of Economic Cooperation and Development) countries during the mid to late 1980s. During the latter part of the twentieth century, due to the rapid technological advancements resulting from, inter alia, computerization and globalization the world economies have faced unprecedented restructuring in production allocation. In addition to sectoral shifts in economic activity, greater concern regarding climate change and pollutant emission led to a simultaneous restructuring in energy consumption patterns. Many developed countries started to shift from fossil fuels to renewable energy sources. Although it is a widely-held view that these structural changes would eventually affect unemployment, there is a paucity of studies on the dynamic relationship between changes in production and energy consumption scenarios and unemployment. This article aims to fill this gap in the literature by investigating this dynamic relationship among sectoral economic activities, macro expenditure patterns, renewable and nonrenewable energy consumption and unemployment in 41 countries from 1980 to 2011. This study will add to the ongoing debate on the rise of unemployment due to restructuring and the impact of pollution abatement measures on climate change effects and employment.

This article seeks to contribute to the literature on the dynamic nexus among sectoral economic activities, government expenditure, renewable and non-renewable energy consumption and unemployment by using both linear and non-linear panel data econometric models. This is perhaps one of the first studies that analyses this dynamic 
relationships between sectoral restructuring, emission and unemployment. In addition to conventional panel unit root tests, we conduct the $\operatorname{LM}(\lambda)$ test of Carrion-i-Silvestre et al. (2005) for unit root and Westerlund (2006) cointegration procedures allowing structural breaks in the series. We also implement second generation linear panel models along with two very recent non-linear panel techniques, Emirmahmutoglu and Omay's (2014) unit root test and Kapetanios et al.'s (2014) non-linear panel estimations under cross sectional dependence. Thus, this study yields a number of empirical results. However, the key finding is that industrialization, services sector, government expenditure and trade openness play a positive role in reducing unemployment, while agriculture and renewable energy consumption increase unemployment. Finally, we extend our analysis by using alternative approaches such as autoregressive distributed lag (ARDL) technique and structural regime-threshold model due to Enders and Granger (1998) and Hansen (1999) to check robustness of our results. However, the findings are consistent across these approaches.

The reminder of this article is structured as follows. The next section offers a critical review of the earlier literature related to unemployment and sectoral restructuring, followed by the theoretical model in section 3. A description of the econometric methodologies and data sources are presented in section 4. Section 5 provides an analysis of the empirical results, while Section 6 performs robustness check and Section 7 concludes the paper.

\section{Unemployment and sectoral changes: a critical review}

Since its inception, economic theory has given significant attention to structural change (Quesnay, 1758; Turgot, 1766; and Steuart 1767). While for Adam Smith (1776), structural features were strongly related to the level of economic development, for Ricardo (1817) changing composition of the productive system was a requisite for economic growth. Although the concept of structural change has been defined in different ways in the literature, the most commonly used meaning is the long-term and persistent shift in the sectoral composition of economic systems (Chenery et al., 1986; Syrquin, 2007). More precisely, structural change is linked with modifications in the relative importance of different sectors over time, measured by their share of output and/or employment.

Around most parts of the globe, the service sector has become the dominant economic activity, while the role of agriculture and manufacturing has declined since 
the 1970s (Memedovic and Iapadre, 2010). Timmer and Akkus (2008) argue that this is a natural developing process, a 'powerful historical pathway to structural transformation,' which leads every country to restructure its economic activities from agriculture to industry and then to services. A cross sectional study of 70 countries by Rowthorn (1994) finds that manufacturing employment increases with per capita income up to a level of US\$12,000 (at 1991 prices). Beyond this threshold, economic growth is accompanied by a decrease of the manufacturing share of total value added. Given the important role played by manufacturing in generating innovation for the entire economic system, this inverse-U pattern is a source of concern. Baumol's law (Baumol, 1967) explains the slowdown in the productivity dynamics of industrialized economies with the rising share of services with less potential for productivity growth, as many service activities are labor intensive (structural change burden). Hence, investigating the impact of these sectoral changes on unemployment is still of great interest to economists and policy makers. However, investigating the effects of restructuring in productive activities, ignoring simultaneous changes in energy consumption patterns, would leave the analysis incomplete.

As global concern about climate change, energy security and high energy prices grows, the world energy industry is experiencing a similar restructuring. Since the Kyoto Protocol was drawn up on 11 December 1997, many developed countries along with their developing counterparts have accelerated the adoption of renewable technologies. Such an expansion of renewable energy consumption impacts on economic activities, such as output and employment. In fact, renewable energy consumption 'significantly influences the vibrancy and sustainability of the entire economy-from job creation to resource efficiency and the environment' (World Economic Forum, 2012). Hence, reduction of energy consumption hinders output growth and thus increases unemployment. Empirical studies on the dynamic relationship between renewable energy consumption and output growth have been studied extensively for different economic regions or countries over the past decade (Salim, et al. 2014; Bloch et al., 2012; Tugcu, et al., 2012). However analysis of dynamic relationship between renewable and/or non-renewable energy consumption and unemployment or employment is lacking. Using a general utility function, Ren and Polasky (2014) finds that the risk of a potential regime shift or sectoral change could cause the optimal management of renewable resources to be precautionary, unchanged, or aggressive as compared to the risk-free case without regime shift. Their results, 
nonetheless, are opposite to those of other recent papers on regime shifts in systems dynamics that show that a regime shift will cause management to be more precautionary (Polasky et al., 2011; de Zeeuw and Zemel, 2012). Hence, any type of structural shift will shift the management decision regarding adoption of renewables.

To the authors' knowledge the only study to examine the direction of causality between energy consumption and employment is Payne (2009) who uses time series data over the period 1976-2006 for Illinois in the US and finds unidirectional causality from energy consumption to employment. Although this study employs time series analysis to investigate linkages between energy consumption and unemployment it does not include other factors such as sectoral restructuring that might also induce increased unemployment. Furthermore, since this study is undertaken for just one US state the results from this study cannot be generalized.

This article seeks to contribute to this literature by investigating the impact of sectoral production (agricultural, manufacturing and service) as well as energy consumption pattern (renewable and non-renewable energy) restructuring on unemployment by using both linear and non-linear panel data estimates.

\section{Analytical Framework}

Building upon the neoclassical framework, the empirical analysis uses in this paper primarily looks at three models to select the appropriate variables of analysis to analyse the unemployment effects of changing energy consumption patterns and structural changes. These three models we have called the production allocation model where the effects on unemployment to changes sectoral production are captured: the macroeconomic expenditure model where the unemployment effects of government expenditure, trade openness and credit availability are captured and the energy consumption model where the unemployment effects of renewable and non-renewable consumption are examined.

In terms of theoretical models that can be used to underpin the empirical analysis, some insights can be gleaned from the theoretical work on structural change by Swiecki (2014) who builds a model that incorporates sector bias technological progress, nonhomothetic tastes, international trade and wage wedges (or differentials) between sectors. Consumer preferences are represented by an indirect utility function, wage wedges or differentials are necessary to capture differences in sectoral shares of unemployment and may be due to sector-specific labour taxes, or differential market 
power due to varying degrees of unionization or just to reflecting worker preferences amongst occupations. Tradeable intermediate goods are introduced into production to capture both trade effects and differences in sector productivity. ${ }^{1}$ Also Finn (2000) develops a model where in an increase in the price of energy works much like an adverse technology shock that contracts economic activity. The channel through which this process occurs is the relationship between energy usage and capital services whereby energy is essential in obtaining the service flow of capital and capital services play an important role in the economy.

This study implements both linear and non-linear panel data econometric procedures based on the above mentioned three separate theoretical settings. The first model based on sectoral production, examines the contribution of sectoral restructuring i.e. agriculture, industry and service, on unemployment. This dynamic relationship can be captured in the following relationship:

$$
\ln U N M_{i t}=\ln \alpha_{1}+\alpha_{2} \ln I N D_{i t}+\alpha_{3} \ln A G R_{i t}+\alpha_{4} \ln S E R_{i t}+\ln e_{i t}
$$

where, UNM, IND, AGR, and SER denote unemployment, industrialization, contribution of agricultural sector to GDP, and contribution of service sector in GDP, respectively. $e$ is the idiosyncratic error term. The subscript $i$ refers to countries and $t$ is time.

The second model, referred to as the expenditure model deals with the impact of three major macroeconomic stimuli on unemployment. These conventional stimuli include government expenditure, trade openness and credit disbursements. Therefore, the linkages can be represented through:

$$
\ln U N M_{i t}=\ln \beta_{1}+\beta_{2} \ln G O V_{i t}+\beta_{3} \operatorname{lnOPN} N_{i t}+\beta_{4} \ln C R D_{i t}+\ln e_{i t}
$$

where, GOV, OPN and CRD represent government expenditure, openness and credit, respectively.

The third model namely, the energy composition model captures the relationship between unemployment with renewable and non-renewable energy consumption. The equation for this energy consumption restructure is:

\footnotetext{
${ }^{1}$ Buera and Kaboski (2009) uses a standard growth model with sector -biased technological progress and non-homothetic tastes to capture the sectoral shifts from manufacturing to services and the subsequent shift in employment shares. McMillan and Rodrik (2014) show that labour flows from high productivity activities to high productive activities are a likely driver of development. They also show that countries with a comparative advantage in natural resources run the risk of stunting their process of structural transformation.
} 


$$
\ln U N M_{i t}=\ln \gamma_{1}+\gamma_{2} \ln R E N_{i t}+\gamma_{3} \ln N R N_{i t}+\ln e_{i t}
$$

where, REN and NRN denote renewable and non-renewable energy, respectively.

\section{Data and Empirical Estimation}

\subsection{Data}

Annual data from 1980 to 2011 were obtained for 41 countries listed in the Appendix Table 1. Data on unemployment rates (U), renewable energy consumption (RE) defined in billions of kilowatt hours, non-renewable energy in quadrillion but, industrialization as industry value added as a percentage of GDP, agriculture as agriculture value added as percentage of GDP, service as service value added as a percentage of GDP, government expenses (G) in billions of constant 2005 U.S. dollars, openness as trade share (TS) indicator ((export + import) / GDP), credit as net domestic credit provided in 2005 U.S. dollars are used. All data, except renewable and non-renewable energy consumption were obtained from world development indicator (WDI), while renewable and non-renewable energy consumption were obtained from energy information administration (EIA).

\subsection{Empirical Estimations}

Given the above theoretical underpinnings, both linear and non-linear panel data estimation procedures are used to identify the determinants of unemployment. This empirical exercise starts with investigating the unit root property of the data. In addition to employing standard linear panel unit root tests of Maddala and Wu (1999), Breitung (2000), Levin et al.(2002) and (Im et al., 2003), this study implements a very recent non-linear panel unit root test due to Emirmahmutoglu and Omay (2014).

If we assume a homogeneous panel then the above models (equations (1) to (3)) can be estimated within standard panel regression techniques like pooled OLS (POLS) and various fixed effects (FE), random effect (RE), or Generalized Method of Moments (GMM) specifications (Sadorsky, 2014). Nonetheless, the assumption that all the factors affecting unemployment across all the forty one countries are homogenous is quite unrealistic. Moreover, in our panel setting we have included countries from different economic, social and cultural backgrounds. Contemporary models with heterogeneous slope coefficients can be estimated using mean group (MG) estimators (Pesaran, 1997; Pesaran and Smith, 1995) or variants of MG estimators. In addition to allowing for heterogeneous slope coefficients across group members, these estimators also account for correlation across panel members (cross sectional dependence). These 
models namely, Mean Group estimator of Pesaran and Smith (1995), Pesaran's (2006) Common Correlated Effects Mean Group (CCEMG) estimator, the Augmented Mean Group (AMG) due to Eberhardt and Teal (2010) and Bond and Eberhardt (2009) are designed for 'moderate- $\mathrm{T}$, moderate- $\mathrm{N}$ ' macro panels, where moderate means from around 15 time-series/cross-section observations (Eberhardt and Teal, 2010). In our case, nevertheless, we employ a panel with $\mathrm{N}=41$ and $\mathrm{T}=32$. Equations 1,2 and 3 can be specified as dynamic panel models of the following forms:

$$
\begin{aligned}
& U N M_{i t}=\alpha_{i} U N M_{2 i t-1}+\beta_{1 i} I N D_{i t}+\beta_{2 i} I N D_{i t-1}+\beta_{3 i} A G R_{i t}+ \\
& \beta_{4 i} A G R_{i t-1}+\beta_{5 i} S E R_{i t}+\beta_{6 i} S E R_{i t-1}+\rho_{1 i}+\varepsilon_{1 i t} \\
& U N M_{i t}=\lambda_{i} U N M_{2 i t-1}+\sigma_{1 i} G O V_{i t}+\sigma_{2 i} G O V_{i t-1}+\sigma_{3 i} O P N_{i t}+ \\
& \sigma_{4 i} O P N_{i t-1}+\sigma_{5 i} C R D_{i t}+\sigma_{6 i} C R D_{i t-1} \rho_{2 i}+\varepsilon_{2 i t} \\
& U N M_{i t}=\chi_{i} U N M_{2 i t-1}+\delta_{1 i} R E N_{i t}+\delta_{2 i} R E N_{i t-1}+\delta_{3 i} N R N_{i t}+ \\
& \delta_{4 i} N R N_{i t-1}+\rho_{3 i}+\varepsilon_{3 i t}
\end{aligned}
$$

Equation (4), (5) and (6) are examples of autoregressive distributed lag (ARDL) models of order one. We can, nonetheless, increase the lag in the right hand side variable. It is worth noting that in this paper lag lengths are chosen based on the Schwarz Information Criteria (SIC).

This study further implements pooled mean group technique to examine the long run and short run Granger causalities between the variables. The residuals, obtained using the long-run estimates are used as dynamic error correction terms. Considering each variable in turn as a dependent variable for each of the three models, the causality between the variables are tested based on the following equations:

$$
\begin{gathered}
\Delta U N M_{i t}=f_{0}+\sum_{j=1}^{m} \gamma_{11 i j} \Delta I N D_{i t-j}+\sum_{j=1}^{m} \gamma_{12 i j} \Delta A G R_{i t-j}+ \\
\sum_{j=1}^{m} \gamma_{13 i j} \Delta S E R_{i t-j}+\zeta_{i t} e_{i t-1}+u_{1 i t} \\
\Delta U N M_{i t}=g_{0}+\sum_{j=1}^{m} \psi_{11 i j} \Delta G O V_{i t-j}+\sum_{j=1}^{m} \psi_{12 i j} \Delta O P N_{i t-j}+ \\
\sum_{j=1}^{m} \psi_{13 i j} \Delta C R D_{i t-j}+\Theta_{i t} \omega_{i t-1}+\varepsilon_{1 i t} \\
\Delta U N M_{i t}=h_{0}+\sum_{j=1}^{m} \theta_{11 i j} \Delta R E N_{i t-j}+\sum_{j=1}^{m} \theta_{12 i j} \Delta N R N_{i t-j}++\tau_{i t} \varphi_{i t-1}+ \\
\varepsilon_{1 i t}
\end{gathered}
$$

The assumption of linearity, however, might not always hold. Hence, this study also employ a recent non-linear panel data estimation model due to Kapetanios et al. (2014) [KMS (2014), hereafter]. Superiority of this model lies in the fact that this model can endogenously generate both 'weak' and 'strong' cross-section dependence. KMS (2014) propose a threshold type dynamic model for multitude of agents (i.e. countries). 
Following KMS (2014), we estimate the full multivariate non-linear panel model under cross sectional dependence as follows:

$$
\begin{aligned}
& y_{i t}=\beta^{\prime} x_{i t}+\varepsilon_{i t}, i=1, \ldots, N, t=1, \ldots, T, \\
& \varepsilon_{i t}=v_{i t}-u_{i t}, \\
& u_{i t}=\alpha_{i}+\rho \tilde{u}_{i t}(r)+\lambda_{i}^{\prime} f_{t}, \\
& \tilde{u}_{i t}=\frac{1}{m_{i t}} \sum_{j=1}^{N} \ell\left(\left|u_{t-1}^{*}-u_{j t-1}\right| \leq r\right) u_{j t-1}, \\
& \text { where } \quad m_{i, t}=\sum_{j=1}^{N} \ell\left(\left|u_{i, t-1}-u_{j, t-1}\right| \leq r\right),
\end{aligned}
$$

where $y_{i t}$ is unemployment, $x_{i t}$ is a vector of independent variables, $\alpha_{i}$ is (unobserved) individual-specific effect, $f_{t}$ is a vector of the heterogeneous loading; $\tilde{u}_{i t}(r)$ represents a cluster effect, which is equal to the average labor market efficiency of countries, which are close to the frontier where $u_{i t}^{*}=\min _{j}\left(u_{j t}-1\right)$ and $v_{i t}$ is an idiosyncratic disturbance. $\left\{\epsilon_{i, t}\right\}_{t=1}^{T}$ is an error process, $\ell($.$) is the indicator function and$ $-1<\rho<1$. To put the above mentioned model in words, it states that $u_{i, t}$ is influenced by cross-sectional average of a selection of $u_{j, t-1}$ and to be precise $u_{j, t-1}$ are those that lie in close proximity to $u_{i, t-1}$. The model involves a $K$ nearest neighbor mechanism except that it is within the data generating process (DGP), not as a technique to estimate an unknown function; therefore, all neighbors $u_{j, t-l}$ within a given threshold, $r$, contribute equally. The interaction term in equation (13) may then be considered as capturing the (cross sectional) local average or common components of their views. As can be seen, model (13) holds considerable resemblance to threshold autoregressive (TAR) models. Unlike a straightforward extension to a panel data setting whereby individual countries would not have (any) interactions, the non-linearity in equation (13) is inherently cross sectional. We further estimate $\hat{r}$ and $\hat{\rho}$ jointly by minimizing,

$$
\begin{aligned}
& V(r, \rho)={ }_{r, \rho}^{\min } \sum_{i=1}^{N} \sum_{t=1}^{T}\left(\hat{e}_{i t}-\rho \frac{1}{m_{i t}} \sum_{j=1}^{N} \ell\left(\left|\hat{e}_{t-1}^{*}-\hat{e}_{j t-1}\right| \leq r\right) \hat{e}_{j t-1}\right)(15 \\
& \hat{e}_{i t}=\max _{i}\left(\hat{u}_{i t}\right)-\left(\hat{u}_{i t}\right)=\max _{i}\left(\hat{\alpha}_{i}+\hat{\rho} \tilde{u}_{i t}(\hat{r})+\hat{\lambda}_{i}^{\prime} f_{t}\right)-\left(\hat{\alpha}_{i}+\hat{\rho} \tilde{u}_{i t}(\hat{r})+\right.
\end{aligned}
$$

$\left.\widehat{\lambda}_{i}^{\prime} f_{t}\right)$

\section{Empirical results}

The panel data econometric procedures undertaken in this study starts by first investigating the existence of unit root in the variables. In addition to implementing standard linear unit root tests, this study employs a very recent non-linear test proposed 
by Emirmahmutoglu and Omay (2014). This study also tests for the existence of cross sectional dependence and structural break within the panel data set. Then it performs both linear and non-linear panel estimation processes. Under linear specification, if the variables contain unit roots, it is imperative to examine whether these variables are subject to long run cointegrating relationships. If they are cointegrated, the final step is to detect the long run elasticities and the direction of causality between the variables by applying panel error correction model. This study also undertakes a very recent nonlinear panel data model due to KMS (2014) for the robustness of the results.

At the outset this study implements Maddala and Wu's (1999) version of Dickey and Fuller (1979) and Philips and Perron (1988) tests, Breitung (2000), Levin et al. (2002) and Im et al. (2003) tests to investigate whether the series follow a unit root process. Results for UNM, IND, AGR, SER, GOV, OPN, CRD, REN, and NRN are reasonably consistent indicating that the variables contain unit roots at their levels [Appendix Table 2].

This study further employs a very recent non-linear unit root test offered by Emirmahmutoglu and Omay (2014). This test is particularly appropriate for examining unit root in non-linear asymmetric heterogeneous panels. Table 1 provides the results of this test applied using the Sieve bootstrap method. The empirical distributions of the tests, generated by 5000 replications, are used to obtain $p$-values. For all the tests lag length is chosen using SBC, setting lag length at 8. From $p$-values reported in Table 1, it can be inferred that under exponential smooth transition autoregressive (ESTAR) non-linearity, all the series follow nonstationary processes.

Table 1: Non-Linear Unit Root Test of Emirmahmutoglu and Omay (2014)

\begin{tabular}{lccc}
\hline Level Variable & $\bar{F}_{A E}$ & $\bar{t}_{U O}$ & $\bar{t}_{I P S_{B}^{C}}$ \\
\hline UNM & $10.852^{* *}(0.010)$ & $-3.218^{* * *}(0.050)$ & $-6.770^{*}(0.000)$ \\
IND & $33.501^{*}(0.000)$ & $-7.750^{*}(0.000)$ & $-6.705^{*}(0.000)$ \\
AGR & $8.596^{* *}(0.025)$ & $-2.661^{* * *}(0.085)$ & $-4.077^{*}(0.000)$ \\
SER & $21.955^{*}(0.000)$ & $-3.687^{* *}(0.020)$ & $-5.995^{*}(0.000)$ \\
GOV & $11.407 * *(0.020)$ & $-4.687^{*}(0.005)$ & $-4.747^{*}(0.000)$ \\
OPN & $8.711^{* *}(0.010)$ & $-4.119^{* *}(0.010)$ & $-4.917 *(0.000)$ \\
CRD & $13.689^{*}(0.000)$ & $-4.549^{*}(0.000)$ & $-5.900^{*}(0.000)$ \\
REN & $12.317^{* *}(0.015)$ & $-2.519(0.160)$ & $-4.568^{*}(0.000)$ \\
NRN & $8.350^{* *}(0.010)$ & $-4.088^{* *}(0.010)$ & $-5.180^{*}(0.000)$ \\
\hline
\end{tabular}


Note: $* * *, * *$, and $*$ indicate that the test statistics is significant at $1 \%, 5 \%$, and $10 \%$ levels, respectively. The numbers in the parentheses indicate the bootstrap $p$-values. The UO and IPS tests performed here are second generation tests. B in the IPS test statistics denotes sieve bootstrap approach in line with Chang (2004).

It is not yet sufficient to conclude that all the series follow a nonstationary process as any of these series may have gone through structural breaks. Hence, this study undertakes panel unit root tests with structural breaks following Carrión-i-Silvestre et al. (2005). The results are presented in Table 2. The results from the unit root tests allowing for structural breaks indicate that statistics reject the null hypothesis of stationarity for all the variables in both homogeneous and heterogeneous long-run versions of the test. In addition to testing for stationarity, this test allows for identifying as much as five structural break dates within the series. All the break dates are reported in Table 2.

Quite intuitively all the series have experienced a break around 2010. The significance of 2010 is that this is the second year after the beginning of the Global Financial Crisis. In 2009, most developed economies found themselves in a deep recession. The fallout for global trade, both for volumes and the pattern of trade had been dramatic. The OECD predicts world trade volumes shrank by 13 percent in 2009 from 2008 levels. Breaks around 1990-1991 might also be linked with global recession which started in early 1990 and lasted till March 1991.

Table 2: Panel unit root test with structural breaks

\begin{tabular}{|c|c|c|c|}
\hline \multirow[t]{2}{*}{ Variables } & \multicolumn{2}{|c|}{ Carrion- $i$-Silvestre et al. $(\operatorname{LM}(\lambda))$} & \multirow[t]{2}{*}{ Break Location $\left(\mathrm{T}_{\mathrm{b}}\right)$} \\
\hline & Test & Bootstrap Critical Value (5\%) & \\
\hline \multicolumn{4}{|l|}{ UNM } \\
\hline$\Psi_{\bar{t}}$ & $15.075^{* *}$ & 9.342 & \multirow{2}{*}{$\begin{array}{l}1991,2010,1985, \\
2004\end{array}$} \\
\hline$\Psi_{\overline{L M}}$ & $-4.856^{* *}$ & -4.753 & \\
\hline \multicolumn{4}{|l|}{ IND } \\
\hline$\Psi_{\bar{t}}$ & $-6.213^{* *}$ & -4.837 & \multirow{2}{*}{$\begin{array}{l}\text { 2006, 1980, 2009, } \\
2010,2001\end{array}$} \\
\hline$\Psi_{\overline{L M}}$ & $-6.408 * *$ & -4.837 & \\
\hline \multicolumn{4}{|l|}{ AGR } \\
\hline$\Psi_{\bar{t}}$ & $-4.885 * *$ & -4.127 & \multirow[t]{2}{*}{$2010,2005,1988$} \\
\hline$\Psi_{\overline{L M}}$ & $-4.797 *$ & -4.127 & \\
\hline \multicolumn{4}{|l|}{ SER } \\
\hline$\Psi_{\bar{t}}$ & $10.898 * *$ & 9.055 & \multirow[t]{3}{*}{$2010,2007,2005$} \\
\hline$\Psi_{\overline{L M}}$ & $0.108 * *$ & 0.103 & \\
\hline GOV & & & \\
\hline
\end{tabular}




\begin{tabular}{|c|c|c|c|}
\hline$\Psi_{\bar{t}}$ & $10.295^{* *}$ & 9.216 & 2010 \\
\hline$\Psi_{\overline{L M}}$ & $10.163 * *$ & 9.215 & \\
\hline \multicolumn{4}{|l|}{ OPN } \\
\hline$\Psi_{\bar{t}}$ & $9.493 * *$ & 9.396 & 1983, 1990, 2010, \\
\hline$\Psi_{\overline{L M}}$ & $-5.041 * *$ & -4.863 & \\
\hline \multicolumn{4}{|l|}{ CRD } \\
\hline$\Psi_{\bar{t}}$ & $-5.179 * *$ & -3.374 & 2010 \\
\hline$\Psi_{\overline{L M}}$ & $-5.075^{* *}$ & -4.880 & \\
\hline \multicolumn{4}{|l|}{ REN } \\
\hline$\Psi_{\bar{t}}$ & $10.961 * *$ & 9.185 & 2006, 2010, 2009 \\
\hline$\Psi_{\overline{L M}}$ & $10.332 * *$ & 9.185 & \\
\hline \multicolumn{4}{|l|}{ NRN } \\
\hline$\Psi_{\bar{t}}$ & -5.071 & -4.839 & 2010 \\
\hline$\Psi_{\overline{L M}}$ & -5.118 & -4.839 & \\
\hline
\end{tabular}

Note: The number of unknown structural break is set to be 5. The null of LM $(\lambda)$ test implies stationarity. The Gauss procedure is undertaken based on the code provided by Ng and Perron (2001). The tests are computed using the Bartlett kernel and all the bandwidth and lag lengths are chosen according to 4(T/100) ${ }^{2 / 9}$. The bootstrap critical value allow for cross-section dependence. Individual country break dates are also computed, to be furnished upon request.

Results from these tests are not always reliable if the variables contain crosssectional dependence. Unit root tests assuming cross-sectional independence can have lower power if cross sectional dependence is in existence in data. There are three tests for identifying cross sectional dependence in contemporary panel data econometric literature namely, Friedman (1937), Frees (1995) and Pesaran's (2004) cross sectional dependence (CD) tests. The results of all these three tests are provided in Table 3.

The results from all three tests show that there is enough evidence to reject the null hypothesis of cross-sectional independence. Hence quite reasonably unit root test allowing for cross sectional dependence is warranted. Pesaran's (2007) CIPS (z(t-bar)) test for unit root is implemented in this regard (see Table 4).

Table 3: Cross sectional dependence tests

\begin{tabular}{|c|c|c|c|c|c|c|}
\hline \multirow[t]{2}{*}{ Tests } & \multicolumn{2}{|c|}{ Pesaran } & \multicolumn{2}{|c|}{ Frees } & \multicolumn{2}{|c|}{ Freidman } \\
\hline & CD test & $\mathrm{p}$-value & $\mathrm{CD}(\mathrm{Q})$ test & $P$ value & CD test & p-value \\
\hline \multicolumn{7}{|l|}{ Model I } \\
\hline FE Estimation & $3.409 *$ & 0.0007 & $6.988 *$ & 0.0000 & 49.697 & 0.1400 \\
\hline RE Estimation & $3.457 *$ & 0.0005 & $7.074 *$ & 0.0000 & 50.039 & 0.1328 \\
\hline \multicolumn{7}{|l|}{ Model II } \\
\hline FE Estimation & $6.633^{*}$ & 0.0001 & $7.419 *$ & 0.0000 & $76.195^{*}$ & 0.0005 \\
\hline RE Estimation & $5.450 *$ & 0.0000 & $7.590 *$ & 0.0000 & $67.017 *$ & 0.0047 \\
\hline \multicolumn{7}{|l|}{ Model III } \\
\hline FE Estimation & $5.959 *$ & 0.0000 & $7.141 *$ & 0.0000 & $70.101 *$ & 0.0023 \\
\hline RE Estimation & $5.462 *$ & 0.0000 & $7.108 *$ & 0.0000 & $65.713^{*}$ & 0.0064 \\
\hline
\end{tabular}


The results of the CIPS tests with constant terms further indicate that all the variables contain unit roots at their levels and become stationary in their first difference. According to the unit root tests under different specifications there are substantial evidences that all the variables are non-stationary at their levels containing unit roots. Therefore, panel cointegration tests can be employed to study the long run equilibrium among the variables. For this purpose, this study implements the four error-correctionbased panel cointegration tests developed by Westerlund (2007). The tests are general enough to allow for a large degree of heterogeneity, both in the long-run cointegrating relationship and in the short-run dynamics, and dependence within as well as across the cross-sectional units. The underlying idea is to test for the absence of cointegration by determining whether the individual panel members are error-correcting or not.

Table 4: Panel Unit root test with cross-section dependence

\begin{tabular}{llllll}
\hline Level Variable & CIPS z(t-bar) & $p$-value & Differenced Variable & CIPS z(t-bar) & $p$-value \\
\hline UNM & 3.139 & 0.999 & $\Delta$ UNM & $-8.077^{*}$ & 0.000 \\
IND & 1.362 & 0.913 & $\Delta$ IND & $-12.932 *$ & 0.000 \\
AGR & 0.036 & 0.514 & $\Delta$ AGR & $-15.141^{*}$ & 0.000 \\
SER & 2.214 & 0.987 & $\Delta$ SER & $-13.640^{*}$ & 0.000 \\
GOV & 1.506 & 0.934 & $\Delta$ GOV & $-6.567 *$ & 0.000 \\
OPN & 0.512 & 0.696 & $\Delta$ OPN & $-10.095^{*}$ & 0.000 \\
CRD & -0.578 & 0.282 & $\Delta$ CRD & $-7.701 *$ & 0.000 \\
REN & -0.822 & 0.134 & $\Delta$ REN & $-17.502 *$ & 0.000 \\
NRN & 3.153 & 0.999 & $\Delta$ NRN & $-13.378^{*}$ & 0.000 \\
\hline Note: The Schwarz Information Criterion (SIC) has been used to determine the optimum lag length. ***,**, and * indicate that \\
the test statistics is significant at $10 \%, 5 \%$, and $1 \%$ levels, respectively. & &
\end{tabular}

According to the results for all four (two group, two panel) statistics reported in Table 5, it can be inferred that there exist long run cointegrating relationships among the variables under all three model specifications. This study further implements Johansen and Fisher cointegration test as proposed by Maddala and Wu (1999). The results of this test are presented in Appendix Table 3 and all the results lend support to conintegrating relationships in all three equations.

Table 5: Westerlund (2007) cointegration test

\begin{tabular}{lll}
\hline Statistic & Value & $p$-value \\
\hline Model I & & \\
Group-t & $-7.839 * *$ & 0.036 \\
Group-a & $-4.268 * * *$ & 0.000 \\
Panel-t & $-14.450 * *$ & 0.021 \\
Panel-a & $-4.403 * * *$ & 0.057 \\
Model II & & \\
Group-t & $-2.590^{*}$ & 0.008 \\
Group-a & $-8.085^{* * *}$ & 0.000
\end{tabular}




\begin{tabular}{lll} 
Panel-t & $-14.528^{* *}$ & 0.017 \\
Panel-a & $-0.711^{* * *}$ & 0.000 \\
Model III & & \\
Group-t & $-3.187^{* *}$ & 0.040 \\
Group-a & $-3.452^{* * *}$ & 0.002 \\
Panel-t & $-14.316^{* *}$ & 0.034 \\
Panel-a & $-4.308^{* * *}$ & 0.000 \\
\hline
\end{tabular}

Notes: $* * *, * *$, and $*$ indicate statistical significance at $10 \%, 5 \%$, and $1 \%$ levels, respectively. Following Westerlund (2007), the maximum lag length is selected according to $4(\mathrm{~T} / 100)^{2 / 9}$. The null hypothesis is 'no cointegration'. The AIC criterion is used to determine the optimum lag length.

It is now established through all the diagnostic tests that there are long run relationships between unemployment and all other independent variables. Therefore, estimating the long run elasticities is warranted. We estimate these elasticities based on both linear and non-linear models under cross sectional dependence. Based on three heterogeneous linear panel estimations the long run elasticities are reported in Table 6.

As reflected by the long run elasticities, only government expenditure, trade openness and nonrenewable energy consumption can significantly reduce unemployment. To be precise, unemployment elasticities with respect to government expenditure, trade openness and nonrenewable energy consumptions vary from -0.607 to $-1.702,-0.465$ and -0.567 , respectively. The inverse relationship between nonrenewable energy consumption and unemployment is consistent with Payne (2009) who found a long run unidirectional causality from energy consumption to employment in Illinois. However, the linear panel estimations failed to identify any impact of the structural changes in production sectors on unemployment.

Table 6: Linear unemployment elasticities

\begin{tabular}{|c|c|c|c|c|c|c|c|c|c|}
\hline \multirow{2}{*}{$\begin{array}{l}\text { Elasti } \\
\text { cities }\end{array}$} & \multicolumn{3}{|c|}{ Model I } & \multicolumn{3}{|c|}{ Model II } & \multicolumn{3}{|c|}{ Model III } \\
\hline & MG & CCEMG & AMG & MG & CCEMG & AMG & MG & CCEMG & AMG \\
\hline IND & $\begin{array}{l}-1.662 \\
(0.217)\end{array}$ & $\begin{array}{l}-0.449 \\
(0.692)\end{array}$ & $\begin{array}{l}-1.955 \\
(0.213)\end{array}$ & & & & & & \\
\hline AGR & $\begin{array}{l}-0.456 \\
(0.583)\end{array}$ & $\begin{array}{l}0.230 \\
(0.659)\end{array}$ & $\begin{array}{l}-0.548 \\
(0.550)\end{array}$ & & & & & & \\
\hline SER & $\begin{array}{l}1.440 \\
(0.529)\end{array}$ & $\begin{array}{l}2.750 \\
(1.973)\end{array}$ & $\begin{array}{l}0.292 \\
(0.892)\end{array}$ & & & & & & \\
\hline GOV & & & & $\begin{array}{l}-0.0141 \\
(0.953)\end{array}$ & $\begin{array}{l}-1.702 * \\
(0.000)\end{array}$ & $\begin{array}{l}-0.607^{*} \\
(0.002)\end{array}$ & & & \\
\hline OPN & & & & $\begin{array}{l}-0.241 \\
(0.125)\end{array}$ & $\begin{array}{l}-0.465^{* *} \\
(0.043)\end{array}$ & $\begin{array}{l}-0.201 \\
(0.178)\end{array}$ & & & \\
\hline CRD & & & & $\begin{array}{l}0.099 \\
(0.132)\end{array}$ & $\begin{array}{l}0.029 \\
(0.799)\end{array}$ & $\begin{array}{l}0.019 \\
(0.756)\end{array}$ & & & \\
\hline REN & & & & & & & $\begin{array}{c}0.109 \\
(0.259)\end{array}$ & $\begin{array}{l}0.045 \\
(0.578)\end{array}$ & $\begin{array}{l}-0.029 \\
(0.752)\end{array}$ \\
\hline NRN & & & & & & & -0.085 & $-0.567 * *$ & -0.308 \\
\hline
\end{tabular}


Note: $* * *, * *$, and $*$ indicate that the test statistic is significant at 10\%, 5\%, and $1 \%$ levels, respectively. Elasticities are based on Pesaran and Smith (1995) Mean Group estimator (MG), Pesaran (2006) Common Correlated Effects Mean Group estimator (CCEMG) and Augmented Mean Group estimator (AMG) was developed in Eberhardt and Teal (2010). $p$-values are provided in the parenthesis.

This study further performs Granger causality tests based on pooled mean group technique. The results are presented in Table 7. The negative signs for all the error correction terms confirm that the mechanisms of short adjustments toward the long run equilibrium are in existence with respect to all the models. The causality results are pretty consistent with the long run elasticities presented earlier. However, in addition to finding unidirectional causalities from government expenditures, credit and nonrenewable energy consumption, the $\chi_{2}$ statistics reveal short run unidirectional causalities from service sector and renewable energy consumption, as well.

As the model specifications do not always follow a linear process, this study employs a non-linear panel data estimation procedure to ensure the robustness of the findings. There are other models of non-linear panel data estimation like Gonzalez et al. (2005) as implemented by Apergis and Salim (2015). The KMS (2014) model, nonetheless, allows for cross sectional dependence which has tested positive with regards to the panel data sets we are using. Hence, this study undertakes a very recent non-linear panel estimation technique under cross sectional dependence due to Kapetanios et al. (2014). The results of non-linear panel estimation allowing for cross sectional dependence are presented in Table 8.

Table 7: Panel causality test based on pooled mean group analyses (PMG)

\begin{tabular}{|c|c|c|c|c|c|c|c|c|c|}
\hline \multirow{2}{*}{$\begin{array}{l}\text { Depnt. } \\
\text { Variable }\end{array}$} & \multicolumn{8}{|c|}{ Sources of causation } & \multirow{2}{*}{$\begin{array}{l}\text { Long } \\
\text { Run }\end{array}$} \\
\hline & Short ru & $\left(\chi^{2}\right)$ & & & & & & & \\
\hline UNM & $\Delta \mathrm{IND}$ & $\Delta \mathrm{AGR}$ & $\Delta$ SER & $\Delta \mathrm{GOV}$ & $\triangle \mathrm{OPN}$ & $\triangle \mathrm{CRD}$ & $\triangle \mathrm{REN}$ & $\triangle N R N$ & ECT \\
\hline Model I & $\begin{array}{l}0.03 \\
(0.86)\end{array}$ & $\begin{array}{l}0.65 \\
(0.42)\end{array}$ & $\begin{array}{l}4.25^{* *} \\
(0.03)\end{array}$ & & & & & & $\begin{array}{l}-0.113 * \\
(0.00)\end{array}$ \\
\hline Model II & & & & $\begin{array}{l}8.13 * \\
(0.00)\end{array}$ & $\begin{array}{l}16.24 * \\
(0.00)\end{array}$ & $\begin{array}{l}2.05 \\
(0.15)\end{array}$ & & & $\begin{array}{l}-0.55^{*} \\
(0.00)\end{array}$ \\
\hline Model III & & & & & & & $\begin{array}{l}7.11 * * \\
(0.01)\end{array}$ & $\begin{array}{l}12.69 * \\
(00)\end{array}$ & $\begin{array}{l}-0.11 * \\
(0.00)\end{array}$ \\
\hline
\end{tabular}

Notes: $\chi^{2}$ tests have been undertaken for short-run analyses. $p$-values are provided in the parentheses. ETC indicates estimated error correction terms. The Schwarz Information Criterion (SIC) has been used to determine the optimum lag length. : **, **, and $*$ indicate that the test statistic is significant at $10 \%, 5 \%$, and $1 \%$ levels, respectively.

Table 8: KMS (2014) threshold non-linear model of cross sectional dependence 


\begin{tabular}{llll}
\hline Elasticities & Model 1 & Model II & Model III \\
\hline$\beta_{I N D}$ & $-0.983^{* *}$ & & \\
& $(0.019)$ & & \\
$\beta_{A G R}$ & $0.064^{*}$ & & \\
& $(0.004)$ & & \\
$\beta_{S E R}$ & $-1.114^{* * *}$ & & \\
& $(0.032)$ & & \\
$\beta_{G O V}$ & & $-0.891^{* *}$ & \\
& & $(0.019)$ & \\
$\beta_{O P N}$ & & $-0.223^{*}$ & \\
$\beta_{C R D}$ & & $(0.012)$ & \\
$\beta_{R E N}$ & & 0.026 & $0.054^{*}$ \\
$\beta_{N R N}$ & & $(0.143)$ & $(0.005)$ \\
& & & $-0.021^{*}$ \\
$r$ & & & $(0.004)$ \\
$\rho$ & & & 0.140 \\
& & & $-0.913^{* * *}$ \\
& & & $(0.054)$ \\
\hline
\end{tabular}

Note: These are the PCCE-KMS estimators proposed by Pesaran (2006) where $f_{t}=\left\{\bar{y}_{t}, t\right\}$. $\mathrm{r}$ and $\rho$ are the threshold and the spatial autoregressive parameters. .***,**, and * indicate that the test statistic is significant at $10 \%, 5 \%$, and $1 \%$ levels, respectively.

All the spatial parameters of the KMS (2014) estimation are significant and less than 1 indicating that the least squares estimators of $(\rho, r)$ are consistent (theorem 1 of Kapetanios et al. (2014)). According to the results, all the coefficients except credit are significant for all the models. According to Model I results, long run elasticity of unemployment with respect to industrialization, agriculture and service sectors are0.983, 0.064 and 1.114, respectively. To explain, a one percent increase in industrialization and service sector would reduce unemployment by $0.983 \%$ and $1.114 \%$, respectively; while one unit increase in agriculture sector is expected to increase unemployment by 0.064 . This might be the case as agriculture industry is becoming increasingly capital intensive. With respect to model II, both government expenditure and trade openness reduce unemployment by $0.891 \%$ and $0.223 \%$. While nonrenewable energy reduces unemployment by $0.054 \%$, renewable energy adoption increases unemployment by $0.054 \%$. This latter finding, might be caused by the increasing trend of capital intensive investment in renewable industry like in nuclear, wind and hydro. 


\section{Robustness tests: Time Series and Panel Estimations across countries, economic}

\section{clusters and regimes}

To test the robustness of our results three different econometric strategies are undertaken. First, we investigate time-series based short- and long-run relationships by implementing the autoregressive distributed lag (ARDL) technique in the context of two developed and two emerging countries. Second, we divide our aggregate panel into two sub-panels consisting of high income and low \& medium (according to World Bank country classification) income countries and perform mean group-type analyses. And third, given the identification of the break points above (Table 2), we contribute to the literature by examining how the nonlinear interactions among unemployment and the set of independent variables change as the economies move through the different regimes (i.e. before and after 2010) as defined by the break points.

With regards to our time series estimations, we consider two developed and two emerging economies. While selecting these countries we tried to choose comparatively stable yet diversified economies namely, France, Germany, China and Costa Rica. Results for these countries are reported in Appendix Table 4 through 7. According to both of the developed countries' results while industrialization and non-renewables decrease unemployment, agriculture increases it. This might be due the transformation of the agricultural sector into capital intensive industries in the developed world. For Germany, credit increases unemployment and government expenditure and service sector reduce it. Whereas for France, renewables industry increases unemployment and openness has a positive impact on the labor market. This result may not be welcoming for the environmentalists in France. However, with time the expansion of renewables industries will create more jobs in future. With respect to two developing countries, credit increases unemployment, whereas non-renewable energy consumption and service sector help improve the labor market outcome. For Costa Rica trade liberalization and industrialization and for China government expenditure and agricultural sector help reduce unemployment. Likewise France, renewables play detrimental role in Costa Rica as far as unemployment is concerned. Hence, our time series results are consistent with our previous findings that industrialization, government expenditure and non-renewables decrease unemployment while credit and service industry increase unemployment.

We also perform two separate panel estimations for high and low \& medium income countries. Their results are reported in Tables 8 and 9 respectively. Our results 
are consistent with the pervious times series results as, for high income countries, industrialization, service industry, government expenditure and non-renewables reduce unemployment while agriculture sector increases unemployment. Whereas for low \& medium income countries trade openness and non-renewables play a positive role, but credit is detrimental to the labor market outcome.

As mentioned earlier, our last strategy is based on two regimes as identified by the structural break test. In order to do that, we estimate a structural regime-threshold model. This modification is inspired by the seminal contribution of Enders and Granger (1998) and Hansen (1999), which permits regimes to be identified by the one or multiple threshold variables. This methodological approach allows us to investigate how the dynamics of our benchmark models change conditional on the stage of the imposed thresholds identified at an earlier stage of the empirical analysis. The new specification of our models yields:

Model 1

$\Delta U N M_{i t}=\left[a_{11} \Delta I N D_{i t}+a_{12} \Delta A G R_{i t}+a_{13} \Delta S E R_{i t}\right] \ell\left(\Delta U N M_{i t} \leq 2010\right)+$
$\left[a_{14} \Delta I N D_{i t}+a_{15} \Delta A G R_{i t}+a_{16} \Delta S E R_{i t}\right] \ell\left(\Delta U N M_{i t}>2010\right)+v_{1 i t}$

Model 2

$\Delta U N M_{i t}=\left[b_{11} \Delta G O V_{i t}+b_{12} \Delta O P N_{i t}+b_{13} \Delta C R D_{i t}\right] \ell\left(\Delta U N M_{i t} \leq 2010\right)+$

$\left[b_{14} \Delta G O V_{i t}+b_{15} \Delta O P N_{i t}+b_{16} \Delta C R D_{i t}\right] \ell\left(\Delta U N M_{i t}>2010\right)+v_{2 i t}$

Model 3

$\Delta U N M_{i t}=\left[c_{11} \Delta R E N_{i t}+c_{12} \Delta N R N_{i t}\right] \ell\left(\Delta U N M_{i t} \leq 2010\right)+\left[c_{13} \Delta R E N_{i t}+\right.$

$\left.c_{14} \Delta N R N_{i t}\right] \ell\left(\Delta U N M_{i t}>2010\right)+v_{3 i t}$

where $\ell($.$) is the indicator function, while the remaining variables have been defined$ before. The estimated parameters of all three models are reported in Appendix Table 10. Although there is no significant finding from the first regime, the second regime estimations are very powerful. Consistently enough, while industrialization and service sector reduce unemployment agriculture increases unemployment. This may be caused by the increased substitution of employment by technology in agriculture in recent times. Likewise our previous analysis renewable energy consumption also induces unemployment while government expenditure, trade openness and non-renewable energy consumption reduce unemployment. 


\section{Conclusion}

This article attempts to analyze the impact of sectoral production allocation, energy usage patterns and macroeconomic expenditure scenarios on unemployment in a panel of forty one countries using both linear and non-linear panel data models. Prior to estimating long run elasticities and short run causalities among the variables, paper extensive diagnostic tests including linear and non-linear stationary tests, tests for panel structural break, cross sectional dependence and cointegration were carried out. With respect to linear estimation, three different heterogeneous dynamic mean group type panel models were used, while a recent non-linear panel data estimation procedure allowing for cross sectional dependence was implemented.

According to the linear panel estimation, only government expenditure, trade openness and nonrenewable energy consumption significantly reduce unemployment. Although linear models contribute very little, non-linear model of Kapetanios et al. (2014) seem to be more powerful in drawing significant inferences. According to the non-linear models, while both industrialization and value addition due to service sector seem to play a positive role in reducing unemployment, agriculture increases unemployment. This might be due to capital-intensive technological advancements in the agricultural sector which require less labor, the non-linear model further indicated that government expenditure and trade openness helped in reducing unemployment. With respect to the energy sector, renewable energy consumption and non-renewable energy consumption act in opposite direction as far as their impact in unemployment is concerned. While fossil fuel consumption reduces unemployment, surprisingly renewable energy consumption increases it. This might be due to the capital intensive nature of nuclear, wind and hydro projects. Hence, we can conclude that there are signs of increases structural unemployment due to accelerated structural changes in energy and production sectors of the economies. In terms of policy implications, given that the government is concerned with pollution abatement, climate change and the use of nonrenewable resources, it has to rely on encouraging trade openness, growth of the service sector (such as financial services) and its own expenditure to reduce unemployment. Part of the response should also include training or re training workers for work in export industries.

We further identify the determinants of unemployment with respect to high and low \& medium income countries, we find that for high income countries, industrialization, service industry, government expenditure and non-renewables reduce 
unemployment while agriculture increases unemployment. Whereas for low \& medium income countries trade openness and non-renewables play a positive role, credit is detrimental to the labor market outcome. Hence, while combating unemployment, policymakers need to be mindful about choosing the right tools as the effectiveness of these instruments is dependent on the economic state of individual countries. Having one policy prescription may be successful for one economy, but may not necessarily be beneficial to another economy. 


\section{References}

A. de Zeeuw, A. Zemel 2012, Regime shifts and uncertainty in pollution control. Journal of Economic Dynamics and Control 36, 939-950.

Apergis, N., Payne, J.E., 2012. Renewable and non-renewable energy consumption-growth nexus: Evidence from a panel error correction model. Energy Economics 34, 733-738.

Apergis, N., Salim, R. 2015. Renewable energy consumption and unemployment: Evidence from a sample of 80 countries and nonlinear estimates, Applied Economics, (forthcoming) DOI:10.1080/00036846.2015.1054071.

Baumol, W.J., 1967. Macroeconomic of unbalanced growth: the anatomy of urban crises. The American Economic Review, 415-426.

Bloch, H., Rafiq, S., Salim, R.A., 2012. Coal consumption, $\mathrm{CO}_{2}$ emission and economic growth in China: Empirical evidence and policy responses. Energy Economics 34, 518-528

Bond, S., Eberhardt, M., 2009. Cross-section dependence in nonstationary panel models: A novel estimator, Paper presented in the Nordic Econometrics Conference in Lund, Sweden.

Breitung, J., 2000. The local power of some unit root tests for panel data. Adv. Econometrics $15,161-178$.

Buera F J and J P Kaboski 2009. Can traditional theories of structural change fit the data? Journal of the European Economic Association 7, 2/3 pp: 469-477.

Carrion-i-Silvestre, J.L., Barrio, T.D., Lopez-Bazo, E., 2005. Breaking the panels. An application to the GDP per capita. Econometrics J. 8, 159-175.

Chenery H., S.R.a.M.S., 1986. Industrialization and growth, A comparative study. Published for the World Bank, Oxfrod University Press.

Comin, D., Lashkari, D. and Mestieri, M. (2015) Structural Change with Long-run Income and Price Effects, Department of Economics, Working Paper, Dartmouth College, Hanover, USA, NH 03755.

Dickey, D.A., Fuller, W.A., 1979. Distribution of estimators for time series regressors with a unit root. Journal of the American Statistical Association 74, 427-431.

Eberhardt, M., Teal, F., 2010. Productivity analysis in global manufacturing production, Economics Series Working Papers. University of Oxford.

Emirmahmutoglu, F., Omay, T., 2014. Reexamining the PPP hypothesis: A nonlinear asymetric heterigeneoud panel unit root test. Economic Modelling 40, 184-190.

Enders, W., Granger, C., W., J., 1998. Unit root tests and asymmetric adjustment with an example using the term structure of interest rates. Journal of Business and Economic Statistics 16, 304-311.

Finn, M. G. 2000. Perfect Competition and the Effects of Energy Price Increases on Economic Activity, Journal of Money, Credit, and Banking 32: 400-416.

Forum, W.E., 2012. Energy for economic growth Energy version update 2012, Geneva, Switzerland.

Frees, E.W., 1995. Assessing cross-sectional correlation in panel data. Journal of Econometrics 69, 393-414.

Friedman, M., 1937. The use of ranks to avoid the assumption of normality implicit in the analysis of variance. Journal of the American Statistical Association 32, 675-701.

Gonzalez, A., Terasvirta, T., Dijk, D., 2005. Panel smooth transition regression models, Working Paper Series in Economics and Finance. Stockholm School of Economics, Sweden.

Hansen, B., E., 1999. Threshold effects in non-dynamic panels: Estimation, testing, and inference. Journal of Econometrics 93, 345-368.

Im, K., Pesaran, M.H., Shin, Y., 2003. Testing for unit root in hetrogeneous panels. J. Econometrics 115, 53-74.

Kapetanios, G., Mitchell, J., Shin, Y., 2014. A nonlinear panel data model of cross-section dependence. Journal of Econometrics 179, 134-157.

Layard, R., S., Nickell, S., Jackman, R., 1991. Unemployment. Oxford University Press, Oxford.

Levin, A., Lin, C.-F., Chu, C.S.J., 2002. Unit root tests in panel data: Asymptotic and finite sample properties. J. Econometrics 108, 1-24. 
Lilien, D.M., 1982. Sectoral shifts and clynical unemployment. Journal of Political Economy 90, 777-793.

Ljungqvist, L., Sargent, Thomas, J., 1998. The european unemployment dilemma. The Journal of Political Economy 105, 514-550.

McMillan, M. S., Rodrik, D. and Verduzco-Gallo, I. 2014. Globalization, Structural Change and Productivity Growth with an update on Africa, World Development 63, PP: 11-32.

Maddala, G.S., Wu, S., 1999. A comparative study of unit root tests with panel data and a new simpletest. Oxford Bull. Econ. Statist. 61, 631-652.

Memedovic, O., Iapadre, L., 2010. Structural change in the world economy: Main features and trends, in: Branch, R.A.S. (Ed.), Working paper United Nations Industrial Development Organization, Vienna.

Newell, A., Pastore, F., 2000. Regional unemployment and industrial restructuring in Poland, Labor Markets in Transition. IZA, Bonn, Germany.

Payne, J.E., 2009. On the dynamics of energy consumption and employment in Illinois. The Journal of Regional Analysis and Policy 39, 126-130.

Pesaran, M.H., 1997. The role of economic theory in modelling the long run. Econ. J. 107, 178191.

Pesaran, M.H., 2004. General diagnostic tests for cross section dependence in panels, Cambridge Working Papers in Economics. University of Cambridge (June).

Pesaran, M.H., 2006. Estimation and inference in large heterogeneous panels with a multifactor error structure. Econometrica 74, 967-1012.

Pesaran, M.H., 2007. A simple panel unit root test in the presence of crossection dependence. J. App. Econ. 22, 265-312.

Pesaran, M.H., Smith, R.P., 1995. Estimating long-run relationships from dynamic heterogeneous panels. J. Eco. 68, 79-113.

Philips, P.C.B., Perron, P., 1988. Testing for a unit root in time series regression. Biometrika $75,12$.

Quesnay, F., 1758. Tableau Économique, in: H. Hagemann, M.L.a.R.S. (Ed.), The Economics of Structural Change Edward Elgar, International Library of Critical Writings, Cheltenham.

Ren, B., S. Polasky 2014, The optimal management of renewable resources under the risk of potential regime shift. Journal of Economic Dynamics and Control 40, 195-212.

Ricardo, D., 1817. The Principles of Political Economy and Taxation, in: Hagemann, H., M. Landesmann and R. Scazzieri (Ed.), Critical Writings. Edward Elgar, Aldershot.

Rowthorn, R., 1994. Korea at the cross-roads, Working Paper, No. 11. ESRC Centre for Business Research, Cambridge University.

S. Polasky, A. de Zeeuw, F. Wagener 2011. Optimal management with potential regime shifts. J. Environ. Econ. Manag. 62, 229-240.

Sadorsky, P., 2014. The effect of urbanization on $\mathrm{CO}_{2}$ emissions in emerging economies. Energy Economics 41, 147-153.

Salim, R. Hassan, Kamrul and Shafiei, S., (2014) Renewable and non-renewable energy consumption and economic growth: Further evidence from OECD countries Energy Economics, 44: 350-360

Serena Ng \& Pierre Perron, 2001. LAG Length Selection and the Construction of Unit Root Tests with Good Size and Power, Econometrica, Econometric Society, 69, No. 6, 1519-1554.

Smith, A., 1776. An inquiry into the nature and causes of the wealth of nations. Clarendon Press, 1976, Oxford.

Steuart, J. (Ed.), 1767. An Inquiry into the Principles of the Political Economy. Oliver and Boyd, Edinburgh and London.

Swiecki, T. (2014) "Determinants of Structural Change " Vancouver School of Economics, Working Paper, University of British Colombia, pp 1-57

Syrquin, M., 2007. Kuznets and Pasinetti on the study of structural transformation: Never the Twain shall meet?, Working Paper No. 46. ICER.

Timmer, C. P., and Akkus, S. (2008). The structural transormation as a pathway out of poverty: Analytics, Emperics, and Politics, Center for Global Development, Working Paper 150, July, $1-66$. 
Toda, H.Y., Yamamoto (1995). Statistical inference in Vector Autoregressions with possibly integrated processes. Journal of Econometrics, 66, 225-250

Tugcu, C.T., Ozturk, I., Aslan, A., 2012. Renewable and non-renewable energy consumption and economic growth relationship revisited: evidence from G7 countries. Energy Economics 34, 1942-1950.

Turgot, A.R.J., 1766. Reflections on the Formation and the Distribution of Wealth, in: Meek, R.L. (Ed.), Turgot on Progress, Sociology and Economics. Cambridge University Press, Cambridge, pp. 119-134.

Westerlund, J., 2007. Testing for error correction in panel data. Oxford Bull. Econ. Statist. 69, 709-748. 


\section{Appendix Table 1}

\section{1 country panel}

Argentina, Australia, Austria, Belgium, Brazil, Canada, Chile, China, Costa Rica, Cyprus, Denmark, El Salvador, Finland, France, Germany, Greece, Iceland, Indonesia, Ireland, Italy, Japan, Korea Rep., Luxembourg, Malaysia, Malta, Netherlands, Norway, Pakistan, Panama, Philippines, Portugal, Spain, Switzerland, Syria, Thailand, Trinidad and Tobago, Turkey, United Kingdom, United States, Uruguay, Venezuela.

\section{Appendix Table 2}

Panel unit root tests without structural breaks

\begin{tabular}{|c|c|c|c|c|c|}
\hline Methods & Fisher ADF & Fisher PP & Breitung & LLC & IPS \\
\hline UNM & -1.27560 & 2.09348 & 2.11256 & 0.25683 & -1.66726 \\
\hline$\Delta \mathrm{UNM}$ & $-14.8160 *$ & $-19.3748 *$ & $-11.7285^{*}$ & $-18.1949 *$ & $-17.2656^{*}$ \\
\hline IND & -0.60868 & -0.98960 & 2.78707 & $-32.304 *$ & $-8.91412 *$ \\
\hline$\Delta \mathrm{IND}$ & $-21.0620^{*}$ & -35.3276 & $-9.81136^{*}$ & $-16.1534 *$ & $-26.2276^{*}$ \\
\hline AGR & -0.72487 & -0.02607 & 0.41284 & -0.28839 & -0.95543 \\
\hline$\Delta \mathrm{AGR}$ & $-21.0758 *$ & $-25.2995^{*}$ & $-15.5228 *$ & $-25.234 *$ & $-26.5065^{*}$ \\
\hline SER & 0.15863 & 0.49035 & 2.63469 & $-2.83 * * *$ & -0.01576 \\
\hline$\triangle \mathrm{SER}$ & $-19.8613 *$ & $-29.4972 *$ & $-14.3342 *$ & $-25.2093 *$ & $-24.3953 *$ \\
\hline GOV & 1.67519 & 3.64166 & 4.91291 & 0.13427 & 1.57207 \\
\hline$\Delta \mathrm{GOV}$ & $-13.7297 *$ & $-17.2545^{*}$ & $-6.88211^{*}$ & $-16.4714^{*}$ & $-16.0678^{*}$ \\
\hline OPN & -1.06936 & -0.86519 & -0.84305 & -1.83026 & -0.97590 \\
\hline$\triangle \mathrm{OPN}$ & $-19.6609 *$ & $1105.01 * * *$ & $-15.7267 *$ & $-26.0498 *$ & $-23.8422 *$ \\
\hline CRD & 31.436 & 46.7498 & 1.15331 & 9.41651 & 0.67165 \\
\hline$\triangle \mathrm{CRD}$ & $1089.49 * * *$ & $4563.27 * * *$ & $-16.8709 * * *$ & $-30.2282 * * *$ & $-35.8517 * * *$ \\
\hline REN & 3.91836 & 75.8180 & 0.16786 & 4.27051 & 3.91836 \\
\hline$\triangle \mathrm{REN}$ & $-30.6715 * * *$ & $1049.98 * * *$ & $-11.4233 * * *$ & $-27.7044 * * *$ & $-30.6715^{* * *}$ \\
\hline NRN & 4.52195 & 63.1645 & 1.06399 & 0.42032 & 0.36966 \\
\hline$\Delta \mathrm{NRN}$ & $-27.9330 * * *$ & $829.484 * * *$ & $-10.8192 * * *$ & $-24.6229 * * *$ & $-24.1567 * * *$ \\
\hline
\end{tabular}

Note: UNM, IND, AGR, SER, GOV, OPN, CRD, REN and NRN represent unemployment industrialization, agriculture, service, government expenditure, openness, credit, renewable and non-renewable, respectively. All tests include and intercept and trend. Probabilities of the test statistics are presented in parentheses. $* * *, * *$, and $*$ indicate that the test statistics is significant at 10\%, 5\%, and $1 \%$ levels, respectively. The Schwarz Information Criterion (SIC) has been used to determine the optimum lag length.

\section{Appendix Table 3}

Johansen and Fisher cointegration test

\begin{tabular}{lll}
\hline Model & Fisher statistic (from the trace test) & Fisher statistic (from max eigen value test) \\
\hline Model I & & \\
None & $541.4(0.000)$ & $390.0(0.000)$ \\
At most 1 & $232.7(0.000)$ & $175.1(0.000)$ \\
At most 2 & $126.3(0.000)$ & $150.45(0.000)$ \\
At most 3 & $150.1(0.000)$ & \\
Model II & & $350.7(0.000)$ \\
None & $517.8(0.000)$ & $181.3(0.000)$ \\
At most 1 & $243.4(0.000)$ & $114.0(0.011)$ \\
At most 2 & $133.1(0.000)$ & $117.6(0.006)$ \\
At most 3 & $117.6(0.006)$ & \\
Model III & &
\end{tabular}




$\begin{array}{lll}\text { None } & 2632.000(0.0000) & 2381.000(0.0000) \\ \text { At most } 1 & 2035.000(0.0000) & 1008.000(0.0000) \\ \text { At most 2 } & 1296.000(0.0000) & 604.700(0.0000)\end{array}$

Note: The Schwarz Information Criteria (SIC) is used to determine the optimum lag length. This test is performed under the option of linear deterministic trend. $p$-values are provided in the parenthesis.

\section{Appendix Table 4}

ARDL Long and Short Run Results for France

\begin{tabular}{|c|c|c|c|}
\hline Series & Model I & Model II & Model III \\
\hline \multicolumn{4}{|c|}{$\underline{\text { Long run analysis }}$} \\
\hline IND & $-0.004 * *[0.015]$ & & \\
\hline AGR & $0.959 * *[0.029]$ & & \\
\hline SER & $0.232[0.626]$ & & \\
\hline GOV & & $0.299[0.542]$ & \\
\hline OPN & & $-2.574 * *[0.016]$ & \\
\hline CRD & & $0.227[0.420]$ & \\
\hline REN & & & $2.218 * *[0.035]$ \\
\hline NRN & & & $-0.329 * *[0.037]$ \\
\hline \multicolumn{4}{|c|}{$\underline{\text { Short run analysis }}$} \\
\hline IND & $6.461 * *[0.011]$ & & \\
\hline AGR & $1.630[0.202]$ & & \\
\hline SER & $3.317[0.169]$ & & \\
\hline GOV & & $0.089[0.765]$ & \\
\hline OPN & & $0.627[0.010]$ & \\
\hline CRD & & $0.670[0.431]$ & \\
\hline REN & & & $4.092 * *[0.043]$ \\
\hline $\mathrm{NRN}$ & & & $6.27 * *[0.016]$ \\
\hline $\mathrm{ECM}_{\mathrm{t}-1}$ & $-0.793^{*}$ & $-0.151 * *$ & $-1.412 * * *$ \\
\hline $\mathrm{R}^{2}$ & 0.987 & 0.777 & 0.686 \\
\hline F-Statistics & $18.149 * * *$ & $31.471 * * *$ & $30.682 * * *$ \\
\hline D.W. & 2.877 & 1.263 & 1.526 \\
\hline
\end{tabular}

Note: $(* * *),(* *)$ and $(*)$ indicate 10,5 and 1 per cent level of significance, respectively. Elasticities are given in the long run analysis while for short run $\chi^{2}$ values are reported. ARDL Cointegration F statistics are found to be 7.715, 5.264 and 5.115 which are above upper bounds of 4.197, 4.295 and 4.367 at $95 \%$ level indicating the rejection of null hypothesis of no level effect for Model I, II and III, respectively. 


\section{Appendix Table 5}

ARDL Long and Short Run Results for Germany

\begin{tabular}{|c|c|c|c|}
\hline Series & Model I & Model II & Model III \\
\hline \multicolumn{4}{|c|}{ Long run analysis } \\
\hline IND & $-1.821^{* * *}[0.000]$ & & \\
\hline AGR & $1.135 * *[0.014]$ & & \\
\hline SER & $-1.971 * * *[0.000]$ & & \\
\hline GOV & & $-0.790 * *[0.017]$ & \\
\hline OPN & & $-0.548[0.100]$ & \\
\hline CRD & & $1.039 * * *[0.007]$ & \\
\hline REN & & & $0.130[0.607]$ \\
\hline NRN & & & $-0.771 * * *[0.000]$ \\
\hline \multicolumn{4}{|c|}{$\underline{\text { Short run analysis }}$} \\
\hline IND & $18.336^{* * * *[0.000]}$ & & \\
\hline AGR & $0.578[0.447]$ & & \\
\hline SER & $21.042 * * *[0.000]$ & & \\
\hline GOV & & $3.525 *[0.060]$ & \\
\hline OPN & & $4.075[0.044]$ & \\
\hline CRD & & $4.509[0.034]$ & \\
\hline REN & & & $0.270[0.603]$ \\
\hline NRN & & & $7.450 * * *[0.000]$ \\
\hline $\mathrm{ECM}_{\mathrm{t}-1}$ & $-0.3420 * * *$ & $-0.353 * * *$ & $-0.212 * * *$ \\
\hline $\mathrm{R}^{2}$ & 0.943 & 0.869 & 0.839 \\
\hline F-Statistics & $79.381 * * *$ & $59.882 * * *$ & $72.978 * * *$ \\
\hline D.W. & 1.715 & 0.875 & 0.839 \\
\hline
\end{tabular}

Note: $(* * *),(* *)$ and $(*)$ indicate 10,5 and 1 per cent level of significance, respectively. Elasticities are given in the long run analysis while for short run $\chi^{2}$ values are reported. ARDL Cointegration F statistics are found to be 5.586, 5.238 and 6.712 which are above upper bounds of 4.148, 4.139 and 4.296 at $95 \%$ level indicating the rejection of null hypothesis of no level effect for Model I, II and III, respectively. 


\section{Appendix Table 6}

ARDL Long and Short Run Results for China

\begin{tabular}{|c|c|c|c|}
\hline Series & Model I & Model II & Model III \\
\hline \multicolumn{4}{|c|}{ Long run analysis } \\
\hline IND & $0.175[0.608]$ & & \\
\hline AGR & $-0.505^{* *}[0.000]$ & & \\
\hline SER & $-0.535 *[0.061]$ & & \\
\hline GOV & & $-0.229 * *[0.017]$ & \\
\hline OPN & & $0.236[0.370]$ & \\
\hline CRD & & $0.241 *[0.051]$ & \\
\hline REN & & & $1.409[0.607]$ \\
\hline NRN & & & $-0.716 * *[0.038]$ \\
\hline \multicolumn{4}{|c|}{$\underline{\text { Short run analysis }}$} \\
\hline IND & $0.255[0.614]$ & & \\
\hline AGR & $5.586 * *[0.018]$ & & \\
\hline SER & $3.087 *[0.079]$ & & \\
\hline GOV & & $-8.604 * * *[0.003]$ & \\
\hline OPN & & $0.651[0.420]$ & \\
\hline CRD & & $3.516 *[0.061]$ & \\
\hline REN & & & $1.955[0.162]$ \\
\hline NRN & & & $3.209 * *[0.014]$ \\
\hline $\mathrm{ECM}_{\mathrm{t}-1}$ & $-0.426^{* * *}$ & $-0.366^{* * *}$ & $-0.144 * *$ \\
\hline $\mathrm{R}^{2}$ & 0.967 & 0.976 & 0.949 \\
\hline F-Statistics & $63.910 * * *$ & $20.474 * * *$ & $24.599 * * *$ \\
\hline D.W. & 1.758 & 2.136 & 2.120 \\
\hline
\end{tabular}

Note: $(* * *),(* *)$ and $(*)$ indicate 10,5 and 1 per cent level of significance, respectively. Elasticities are given in the long run analysis while for short run $\chi^{2}$ values are reported. ARDL Cointegration F statistics are found to be 6.835, 5.159 and 5.219 which are above upper bounds of 4.139, 4.164 and 4.366 at $95 \%$ level indicating the rejection of null hypothesis of no level effect for Model I, II and III, respectively. 


\section{Appendix Table 7}

ARDL Long and Short Run Results for Costa Rica

\begin{tabular}{|c|c|c|c|}
\hline Series & Model I & Model II & Model III \\
\hline \multicolumn{4}{|c|}{ Long run analysis } \\
\hline IND & $-13.403^{* *}[0.608]$ & & \\
\hline AGR & $1.290[0.388]$ & & \\
\hline SER & $-10.931 * *[0.042]$ & & \\
\hline GOV & & $-0.112[0.162]$ & \\
\hline OPN & & $-1.981 * * *[0.003]$ & \\
\hline CRD & & $0.427 * * *[0.000]$ & \\
\hline REN & & & $0.841 * * *[0.001]$ \\
\hline NRN & & & $-0.214 * *[0.025]$ \\
\hline \multicolumn{4}{|c|}{$\underline{\text { Short run analysis }}$} \\
\hline IND & $7.757 * * *[0.005]$ & & \\
\hline AGR & $9.049 * * *[0.003]$ & & \\
\hline SER & $23.239 * * *[0.000]$ & & \\
\hline GOV & & $2.333[0.127]$ & \\
\hline OPN & & $16.116 * * *[0.000]$ & \\
\hline CRD & & $17.587 * * *[0.000]$ & \\
\hline REN & & & $13.975 * * *[0.000]$ \\
\hline NRN & & & $3.733 * *[0.043]$ \\
\hline $\mathrm{ECM}_{\mathrm{t}-1}$ & $-0.276^{* *}$ & $-0.667 * * *$ & $-0.346^{* *}$ \\
\hline $\mathrm{R}^{2}$ & 0.873 & 0.762 & 0.726 \\
\hline F-Statistics & $17.279 * * *$ & $19.294 * * *$ & $16.569 * * *$ \\
\hline D.W. & 2.546 & 1.945 & 2.278 \\
\hline
\end{tabular}

Note: $(* * *),(* *)$ and $(*)$ indicate 10,5 and 1 per cent level of significance, respectively. Elasticities are given in the long run analysis while for short run $\chi^{2}$ values are reported. ARDL Cointegration F statistics are found to be 7.848, 5.535 and 5.121 which are above upper bounds of 4.164, 4.164 and 4.286 at $95 \%$ level indicating the rejection of null hypothesis of no level effect for Model I, II and III, respectively. 


\section{Appendix Table 9}

Linear unemployment elasticities for high income countries

\begin{tabular}{|c|c|c|c|c|c|c|c|c|c|}
\hline \multirow[t]{2}{*}{ Elasticities } & \multicolumn{3}{|c|}{ Model I } & \multicolumn{3}{|c|}{ Model II } & \multicolumn{3}{|c|}{ Model III } \\
\hline & MG & $\begin{array}{l}\text { CCEM } \\
\mathrm{G}\end{array}$ & $\mathrm{AMG}$ & MG & $\begin{array}{l}\text { CCEM } \\
\mathrm{G}\end{array}$ & $\mathrm{AMG}$ & MG & $\begin{array}{l}\text { CCEM } \\
\mathrm{G}\end{array}$ & AMG \\
\hline IND & $\begin{array}{l}-1.309^{* * *} \\
(0.096)\end{array}$ & $\begin{array}{l}-0.824 \\
(0.354)\end{array}$ & $\begin{array}{l}-1.313^{* * *} \\
(0.082)\end{array}$ & & & & & & \\
\hline AGR & $\begin{array}{l}0.3683 * * \\
(0.040)\end{array}$ & $\begin{array}{l}0.425^{*} \\
(0.004)\end{array}$ & $\begin{array}{l}0.179 \\
(0.281)\end{array}$ & & & & & & \\
\hline SER & $\begin{array}{l}-1.273 * * \\
(0.028)\end{array}$ & $\begin{array}{l}-1.119 * \\
(0.004)\end{array}$ & $\begin{array}{l}-0.350 * \\
(0.005)\end{array}$ & & & & & & \\
\hline GOV & & & & $\begin{array}{l}-1.116^{* *} \\
(0.044)\end{array}$ & $\begin{array}{l}0.037 \\
(0.941)\end{array}$ & $\begin{array}{l}-0.062 * \\
(0.006)\end{array}$ & & & \\
\hline OPN & & & & $\begin{array}{l}-0.709 * \\
(0.001)\end{array}$ & $\begin{array}{l}-0.265 \\
(0.352)\end{array}$ & $\begin{array}{l}-0.258 \\
(0.213)\end{array}$ & & & \\
\hline CRD & & & & $\begin{array}{l}-0.035 \\
(0.699)\end{array}$ & $\begin{array}{l}-0.155 \\
(0.139)\end{array}$ & $\begin{array}{l}0.039 \\
(0.682)\end{array}$ & & & \\
\hline REN & & & & & & & $\begin{array}{c}0.042 \\
(0.754)\end{array}$ & $\begin{array}{l}0.072 \\
(0.578)\end{array}$ & $\begin{array}{l}0.091 \\
(0.437)\end{array}$ \\
\hline NRN & & & & & & & $\begin{array}{c}-1.068 * \\
(0.001)\end{array}$ & $\begin{array}{l}-0.700 * \\
(0.039)\end{array}$ & $\begin{array}{l}-0.531 \\
(0.112)\end{array}$ \\
\hline
\end{tabular}

Note: $* * *, * *$, and $*$ indicate that the test statistic is significant at $10 \%, 5 \%$, and $1 \%$ levels, respectively. Elasticities are based on Pesaran and Smith (1995) Mean Group estimator (MG), Pesaran (2006) Common Correlated Effects Mean Group estimator (CCEMG) and Augmented Mean Group estimator (AMG) was developed in Eberhardt and Teal (2010). $p$-values are provided in the parenthesis.

\section{Appendix Table 10}

Linear unemployment elasticities for low and medium income countries

\begin{tabular}{|c|c|c|c|c|c|c|c|c|c|}
\hline \multirow[t]{2}{*}{ Elasticities } & \multicolumn{3}{|c|}{ Model I } & \multicolumn{3}{|c|}{ Model II } & \multicolumn{3}{|c|}{ Model III } \\
\hline & MG & CCEMG & AMG & MG & CCEMG & AMG & MG & $\begin{array}{l}\text { CCEM } \\
\text { G }\end{array}$ & $\mathrm{AMG}$ \\
\hline IND & $\begin{array}{l}-2.342 \\
(0.096)\end{array}$ & $\begin{array}{l}-1.623 \\
(0.633)\end{array}$ & $\begin{array}{l}-1.277 \\
(0.701)\end{array}$ & & & & & & \\
\hline AGR & $\begin{array}{l}-2.046 \\
(0.396)\end{array}$ & $\begin{array}{l}-0.805 \\
(0.636)\end{array}$ & $\begin{array}{l}-0.744 \\
(0.676)\end{array}$ & & & & & & \\
\hline SER & $\begin{array}{l}1.760 \\
(0.754)\end{array}$ & $\begin{array}{l}1.788 \\
(0.653)\end{array}$ & $\begin{array}{l}3.118 \\
(0.533)\end{array}$ & & & & & & \\
\hline GOV & & & & $\begin{array}{l}-0.938 \\
(0.241)\end{array}$ & $\begin{array}{l}-0.156 \\
(0.658)\end{array}$ & $\begin{array}{l}-0.332 \\
(0.667)\end{array}$ & & & \\
\hline OPN & & & & $\begin{array}{l}-0.291 \\
(0.316)\end{array}$ & $\begin{array}{l}-0.259 * * * \\
(0.093)\end{array}$ & $\begin{array}{l}-0.275 * * * \\
(0.003)\end{array}$ & & & \\
\hline CRD & & & & $\begin{array}{l}0.165 \\
(0.172)\end{array}$ & $\begin{array}{l}0.177 * * \\
(0.034)\end{array}$ & $\begin{array}{l}0.199 * * * \\
(0.096)\end{array}$ & & & \\
\hline REN & & & & & & & $\begin{array}{l}-0.335 \\
(0.245)\end{array}$ & $\begin{array}{l}0.072 \\
(0.578)\end{array}$ & $\begin{array}{l}-0.301 \\
(0.291)\end{array}$ \\
\hline NRN & & & & & & & $\begin{array}{l}-0.024 \\
(0.940)\end{array}$ & $\begin{array}{l}-0.700 * \\
(0.039)\end{array}$ & $\begin{array}{l}-0.153 \\
(0.616)\end{array}$ \\
\hline
\end{tabular}

Note: $* * *, * *$, and $*$ indicate that the test statistic is significant at $10 \%, 5 \%$, and $1 \%$ levels, respectively. Elasticities are based on Pesaran and Smith (1995) Mean Group estimator (MG), Pesaran (2006) Common Correlated Effects Mean Group estimator (CCEMG) and Augmented Mean Group estimator (AMG) was developed in Eberhardt and Teal (2010). $p$-values are provided in the parenthesis. 
Appendix Table 11

Estimates of the multiple-regime models (full panels)

\begin{tabular}{lccccc}
\hline Model & $\begin{array}{c}1^{\text {st }} \text { Regime } \\
\text { Coefficient }\end{array}$ & $t$-Statistics & & $\begin{array}{l}2^{\text {nd }} \text { Regime } \\
\text { Coefficient }\end{array}$ & $t$-Statistics \\
\hline Model I & & & & & \\
$a_{11}$ & -0.004 & -0.23 & $a_{14}$ & $-1.320^{*}$ & 9.08 \\
$a_{12}$ & -0.003 & -0.58 & $a_{15}$ & $0.327^{*}$ & 7.74 \\
$a_{13}$ & 0.001 & 0.03 & $a_{16}$ & $-0.722^{* *}$ & 2.49 \\
Model 2 & & & & & \\
$b_{11}$ & 0.001 & 0.04 & $b_{14}$ & $-1.240^{*}$ & -10.99 \\
$b_{12}$ & 0.000 & 0.01 & $b_{15}$ & $-0.320^{*}$ & -8.49 \\
$b_{13}$ & 0.000 & 0.02 & $b_{16}$ & -0.026 & -0.80 \\
Model 3 & & & & & 11.09 \\
$c_{11}$ & 0.001 & 0.24 & $c_{13}$ & $0.307^{*}$ & -4.87 \\
$c_{12}$ & 0.000 & 0.07 & $c_{14}$ & $-0.079^{*}$ & \\
\hline
\end{tabular}

Notes: $* * *, * *$, and $*$ indicate that the test statistics is significant at $10 \%, 5 \%$, and $1 \%$ levels, respectively. 